\title{
Upaya pengembangan usaha mandiri di kalangan pengangguran terdidik di Jawa Timur
}

\section{Efforts in developing self-employment in unemployed graduates in East Java}

\author{
Bagong Suyanto $^{1} \&$ Septi Ariadi $^{2}$ \\ Departemen Sosiologi, FISIP, Universitas Airlangga \\ Jalan Airlangga 4-6 Surabaya 60286, Indonesia \\ E-mails: bagong_fisip@yahoo.com dan septi_ariadi@yahoo.com
}

\begin{abstract}
The report study intends to examined several obstacles faced by the graduates of the Faculty of Economics and Business in developing their entrepreneurship, mapping their networking, and formulating contextual intervention program in order to accelerate effort to handle unemployment problem. Data were collected by in-depth interview. After undergo editing and classification processes, data were analyzed and interpreted. The study shows that, even the economic graduates are those who have graduated from a well-known university with GPA were at least of 3.00, they generally do not have the ability and ambision to develop independent business or entrepreneurship. Various theories and experiences which were given during the study in college are generally considered to be less supportive in entrepreneurship development. In many cases, the graduates of the Faculty of Economics and Business prefer to work for someone else. One of the constraint that often encountered by the graduates of Faculty of Economics and Business were the lack of capital and excessive competitor in the field. There was an urgency to improve curriculum and study activity to provide a better media for student to learn entrepenuership.
\end{abstract}

Keywords: educate unemployment, economic graduates, entrepreneurship

\begin{abstract}
Abstrak
Studi yang tengah dilaporkan ini mengkaji berbagai kendala yang dihadapi sarjana lulusan fakultas ekonomi dan bisnis dalam mengembangkan usaha mandiri, memetakan kemampuan mereka dalam membangun jaringan kerja, serta sekaligus merumuskan program intervensi yang benar-benar kontekstual untuk mempercepat upaya penanganan pengangguran, khususnya pengangguran terdidik di Provinsi Jawa Timur. Pengumpulan data melalui wawancara mendalam. Data yang berhasil dikumpulkan, setelah melalui proses editing dan klasifikasi kemudian telah dianalisis dan diinterpretasi. Studi ini menemukan para sarjana ekonomi yang diteliti merupakan lulusan PT terkenal dan memiliki IPK di atas 3.00, tetapi mereka umumnya belum memiliki kemampuan dan ambisi untuk mengembangkan usaha mandiri. Berbagai teori dan pengalaman selama proses pembelajaran di bangku kuliah, umumnya dinilai tidak memberikan manfaat langsung untuk mendukung upaya pengembangan usaha mandiri. Dalam banyak kasus, para sarjana lulusan Fakultas Ekonomi dan Bisnis ini lebih suka bekerja ikut orang lain. Kendala yang acapkali dihadapi sarjana ekonomi ini, adalah keterbatasan modal dan jumlah kompetitor yang terlalu banyak. Diperlukan perbaikan kurikulum dan aktivitas belajar yang lebih memfasilitasi peluang lulusan untuk belajar praktik berbisnis.
\end{abstract}

Kata kunci: pengangguran terdidik, sarjana ekonomi, usaha mandiri

\section{Pendahuluan}

Sesungguhnya ada banyak hal yang harus dilakukan untuk mengeliminasi perkembangan jumlah pengangguran terdidik yang makin hari makin mencemaskan di Provinsi Jawa Timur. Ketika dunia pendidikan tinggi ternyata hanya melahirkan pencari kerja, dan bukan lulusan yang mampu menciptakan pekerjaan dan usaha mandiri secara kreatif, maka mau tidak harus diantisipasi berbagai hal yang sifatnya kontraproduktif. Selain dibutuhkan strategi, kebijakan dan program yang benar-benar kontekstual dan efektif, yang tak kalah penting adalah bagaimana menggugah semua pihak untuk mau lebih peduli terhadap isu penanganan pengangguran terdidik ini. Dengan berkaca pada pengalaman selama ini, peningkatan jumlah pengangguran terdidik yang notabene merupakan kaum intelektual secara umum merupakan 
akibat tiga faktor. Pertama, karena kompetensi mahasiswa dan lulusan Perguruan Tinggi (PT) yang memang kurang mumpuni karena bermental pragmatis atau karena tidak memperoleh proses pembelajaran yang tepat. Kedua, karena jumlah lapangan pekerjaan di Indonesia memang tidak terlalu banyak. Ketiga, karena sistem pendidikan di Indonesia yang terlalu berorientasi ke bidang akademik, sehingga tidak melatih dan mempersiapkan lulusan yang mampu menghadapi situasi pasar dan dunia kerja yang menantang (Suyanto 2006, Yustika 2007).

Selama ini, kurikulum di jenjang pendidikan S-1 yang terlalu menekankan pada pengajaran akademik, langsung maupun tidak langsung menyebabkan munculnya mental sarjana yang hanya bisa mencari kerja tetapi bukan menciptakan lapangan kerja. Hal ini, tentu akan berbeda jika sistem pendidikan vokasi diperbanyak. Dengan pendidikan vokasi yang tepat diprediksi jumlah pengangguran intelektual di Indonesia tidak bakal sebanyak sekarang, karena para lulusan Perguruan Tinggi akan memiliki kemampuan yang memang dibutuhkan pasar dan sesuai dengan kesempatan kerja yang tersedia di dunia kerja.

Berdasar hasil kajian yang telah dilakukan Suyanto et al. (2013), beberapa temuan utama yang menjadi isu prioritas di balik fenomena meluasnya pengangguran terdidik adalah: Pertama, para sarjana dan lulusan Diploma walaupun mereka sebagian adalah jebolan dari PT-PT yang bergengsi, dan sebagian besar memiliki IPK di atas 3, ternyata hal itu bukan jaminan bakal dapat segera memperoleh pekerjaan yang diinginkan. Tidak sedikit lulusan PT ternyata kurang atau bahkan tidak menguasai bahasa Inggris, sehingga kurang memiliki kompetensi sebagaimana diharapkan pasar kerja. Sebagian besar lulusan PT juga tidak memiliki koneksi yang bisa dimanfaatkan untuk mencarikan pekerjaan, sementara di saat yang sama akses mereka pada sumber-sumber permodalan juga kurang. Di tengah iklim persaingan mencari kerja yang makin kompetitif, akhirnya bisa dipahami jika sebagian lulusan PT akhirnya harus menganggur, baik untuk jangka waktu yang kurang dari setahun maupun lebih dari setahun.

Kedua, lebih dari sekadar soal mismatch antara PT dengan kebutuhan pasar tenaga kerja, berbagai persoalan yang muncul di bidang ketenagakerjaan, khususnya munculnya persoalan pengangguran di antara lulusan PT, sesungguhnya sangat kompleks. Faktor-faktor yang menyebabkan seorang lulusan PT tidak segera dapat terserap dalam pasar kerja bukan hanya kompetensi atau kualifikasi lulusan, tetapi juga faktor-faktor sosial-budaya lain, seperti tidak milikinya koneksi, iklim persaingan mencari pekerjaan yang makin ketat, dan keinginan yang berbeda antara pencari kerja dengan kebutuhan pasar kerja.

Ketiga, beberapa kendala yang dihadapi pengangguran terdidik dalam mencari pekerjaan atau mengembangkan usaha mandiri adalah: (1) berkaitan dengan kondisi ekonomi orang tua yang relatif pas-pasan atau bahkan miskin, (2) keterbatasan modal usaha dan akses yang terbatas terhadap sumber-sumber permodalan yang ada, (3) berkaitan dengan dimiliki-tidaknya koneksi yang dapat dimintai bantuan untuk mencari pekerjaan dan membuka akses untuk pengembangan kegiatan ekonomi, dan (4) jumlah kompetitor atau jumlah daftar pencari kerja yang dari waktu ke waktu terus bertambah, langsung atau tidak langsung tentunya akan mempengaruhi peluang para pengangguran terdidik dalam mencari pekerjaan yang diinginkan.

Ketika sistem pendidikan yang dikembangkan PT lebih banyak menghasilkan sarjana akademik, dan bukan sarjana yang memiliki keahlian atau ketrampilan vokasional, implikasinya kemudian memang cenderung terjadi misssmatch antara kualifikasi lulusan PT dengan kebutuhan pasar kerja. Jangankan untuk lulusan PT yang termasuk kurang populer; seperti lulusan ilmu sosial atau ilmu dasar, bahkan untuk lulusan PT dari fakultas yang populer pun, seperti sarjana teknik dan sarjana ekonomi ternyata mereka pun tidak selalu mudah memperoleh pekerjaan atau mengembangkan usaha mandiri. Khusus untuk lulusan 
dari Fakultas Ekonomi dan Bisnis, misalnya, yang seharusnya selama mereka kuliah telah banyak mempelajari persoalan ekonomi dan pasar, itu pun ternyata tidak menjadi jaminan mereka bakal segera terserap dalam pasar kerja apalagi mampu menciptakan lapangan kerja secara mandiri. Meski selama mereka kuliah telah banyak memperoleh pengetahuan teoritis tentang dunia kerja dan juga memiliki kesempatan untuk magang kerja, tetapi ternyata itu semua tidak dengan serta-merta dapat menjadi jaminan bahwa setelah lulus mereka akan dapat mengembangkan usaha yang sifatnya mandiri. Selain keterbatasan modal, keterbatasan akses pada sumber-sumber pemasaran, dan lain sebagainya, sering terjadi lulusan PT di bidang ekonomi dan bisnis pun sulit bersaing dalam iklim pasar kerja yang makin kompetitif.

Di Indonesia, pengangguran, termasuk persoalan pengangguran di kalangan sarjana terdidik, hingga saat ini harus diakui merupakan salah satu masalah di bidang ketenagakerjaan yang belum juga terselesaikan. Meski pun sebuah negara atau daerah mengalami pertumbuhan ekonomi yang tinggi, hal itu tidak menjadi jaminan bahwa tidak akan ada masalah pengangguran atau pencari kerja (Basri 2002). Bisa saja terjadi, sebuah negara atau daerah mengalami pertumbuhan ekonomi yang tinggi, tetapi karena lapangan kerja yang tercipta membutuhkan kualifikasi keahlian tertentu dan juga syarat-syarat lain, maka bukan tidak mungkin di saat yang sama daftar pencari kerja justru malah naik.

Lulusan Perguruan Tinggi sesungguhnya adalah bagian dari angkatan kerja yang potensial, namun ironisnya tidak selalu mereka dapat dengan mudah terserap dalam pasar tenaga kerja karena berbagai alasan. Secara teoritis, problematik yang melanda kaum muda, terutama lulusan PT antara lain bersumber dari kesenjangan yang terjadi antara perubahan struktur demografis, akselerasi program pendidikan, dan besarnya akselerasi pencari kerja yang acapkali tidak sebanding dengan jumlah lapangan pekerjaan yang tersedia (Kuncoro 2003).

Di negara sedang berkembang, pasar tenaga kerja umumnya tersegmentasi menurut tingkat pendidikan. Di atas kertas, kesempatan keja bagi lulusan Perguruan Tinggi biasanya cenderung lebih terbuka, sehingga secara teoritis tingkat pengangguran dari kelompok ini cenderung lebih kecil daripada kelompok yang berpendidikan lebih rendah. Namun demikian, kesempatan kerja itu akan menyempit berseiring dengan meningkatnya jumlah lulusan dari tingkat pendidikan yang lebih tinggi.

Fakta di lapangan justru seringkali memperlihatkan bahwa proporsi terbesar dari para pengangguran adalah mereka yang memiliki pendidikan lebih tinggi. Pendidikan yang lebih tinggi banyak menyebabkan anak muda justru menolak mengerjakan pekerjaan-pekerjaan dengan sistem manual, termasuk pekerjaan di sektor pertanian yang dinilai kurang sesuai dengan tingkat pendidikan mereka. Kalangan terdidik, khususnya lulusan PT cenderung mencari pekerjaan di sektor jasa, padahal pertumbuhan kesempatan kerja di sektor jasa tidak mampu mengimbangi pertumbuhan angkatan kerja terdidik (Titrtosudarmo 1994:24).

Di berbagai darah, khususnya di perkotaan, banyak ditemui para pemuda memilih menganggur daripada melakukan pekerjaan yang dianggap tidak sesuai dengan tingkat pendidikan dan gaji yang diterima juga dinilai terlalu rendah. Gejala ini, terutama terlihat pada kalangan lulusan PT yang secara ekonomi mapan dan belum berkeluarga. Mereka biasanya lebih memilih sementara waktu menganggur karena keluarganya mampu mencukupi kebutuhannya, sampai menemukan pekerjaan yang dianggap sesuai dengan tingkat pendidikannya.

Keberhasilan anak muda untuk menyelesaikan pendidikan hingga jenjang PT, ternyata belum merupakan jaminan mereka segera mendapatkan pekerjaan. Menurut Sirageldin \& Li (dalam Pacione 1986), dalam hal ini paling-tidak terdapat empat faktor yang menentukan perserapan lulusan PT ke dalam pasaran tenaga kerja. Pertama, faktor angkatan kerja, yang meliputi rasio antara mereka yang masuk dengan mereka yang keluar dari angkatan kerja. Kedua, kebutuhan spesifik menyangkut jumlah dan karakteristik yang dibutuhkan oleh sektor industri. Ketiga, faktor simulasi pendidikan yang menyediakan lulusan untuk jenjang-jenjang pekerjaan 
menurut tingkat pendidikannya. Keempat, faktor kebijakan terhadap tenaga kerja yang menentukan penempatan lulusan sekolah atau tenaga kerja pada matriks sektor, jabatan, wilayah maupun penyebaran geografisnya.

Di Indonesia, beberapa faktor yang disinyalir menyebabkan meningkatnya jumlah pengangguran terdidik adalah sebagai berikut: pertama, karena adanya ketidakcocokan antara karakteristik lulusan baru yang memasuki dunia kerja (sisi penawaran tenaga kerja) dengan pasar kerja yang sedang berkembang karena dihela perubahan dan pembangunan. Kedua, karena terbatasnya daya serap tenaga kerja di sektor formal. Kehadiran dan pertambahan tenaga kerja terdidik yang jumlahnya terus berkembang dari waktu ke waktu memberi tekanan yang kuat terhadap kesempatan kerja di sektor formal yang jumlahnya relatif kecil. Ketiga, belum efesiennya fungsi pasar kerja. Di samping faktor kesulitan memperoleh lapangan kerja, arus informasi tenaga kerja yang tidak sempurna dan tidak lancar menyebabkan banyak angkatan kerja bekerja di luar bidang keahlian mereka. Keempat, adanya faktor gengsi yang menyebabkan lulusan akademi atau universitas cenderung lebih memilih menganggur karena tidak sesuai dengan bidangnya.

Lebih dari sekadar soal mismatch antara PT dengan kebutuhan pasar tenaga kerja, berbagai persoalan yang muncul di bidang ketenagakerjaan di antara lulusan PT, sesungguhnya sangat kompleks, dan berkaitan dengan faktor sosial, budaya, ekonomi dan politik. Kebijakan pembangunan yang cenderung pro pertumbuhan dan tidak mengembangkan mekanisme retribusi aset dan pengembangan kualitas sumber daya manusia menyebabkan tenaga kerja yang ada menjadi makin tertinggal dengan kebutuhan pasar kerja (Suyanto \& Karnaji 2005).

Selama ini, upaya untuk mengembangkan usaha mandiri di kalangan pemuda, khususnya para sarjana harus diakui bukanlah hal yang mudah. Antara sarjana satu dengan yang lain, kendala dan permasalahan yang dihadapi umumnya tidaklah sama. Dalam memberdayakan pemuda, secara garis besar ada beberapa kategori pemuda yang perlu diberdayakan. Pertama, pemuda yang sudah punya usaha sederhana tetapi masih membutuhkan bimbingan dan pengembangan. Kedua adalah pemuda yang punya keahlian, tetapi tidak memiliki modal, sehingga belum memiliki usaha mandiri yang dikembangkan. Ketiga adalah pemuda yang punya modal, tetapi tidak memiliki keahlian. Keempat, pemuda yang tidak punya modal dan tidak punya keahlian.

Menurut data Menpora, saat ini angka pengangguran terbuka pemuda di Indonesia tercatat sekitar 19,5 persen. Ini terjadi karena rendahnya kesempatan pemuda dalam mengakses pendidikan, baik formal maupun informal. Namun demikian, di kalangan pemuda yang telah berhasil lulus pendidikan tinggi pun sebetulnya tidak ada jaminan mereka bakal bisa terserap pasar kerja, apalagi mampu mengembangkan usaha yang sifatnya mandiri karena berbagai alasan.

Permasalahan utama yang sering muncul dalam upaya mengembangkan kewirausahaan pemuda adalah karena kurangnya kesadaran akan pentingnya menjadi pemuda yang mandiri dan berwirausaha. Selama ini para pemuda umumnya lebih berorientasi kepada pergerakan politik dan kekuasaan sehingga mereka cenderung memilih cara instan untuk menjadi terkenal dan politisi andal, tetapi dari aspek ekonomi pemuda jauh tertinggal.

Bagi pemuda kendala utama yang mereka hadapi dalam berwirausaha adalah susahnya mendapatkan modal usaha dan tidak adanya jaringan kerja yang bisa mereka manfaatkan untuk mendukung pengembangan usaha yang dirintis atau dikembangkan. Di sisi lain, di lapangan sering terjadi para sarjana susah untuk mengembangkan usaha mandiri karena mereka tidak memiliki etos kewirausahaan yang mendukung. 
Richard Cantillon (2010) menyatakan, yang dimaksud dengan kewirausahaan sesungguhnya adalah bekerja sendiri (self-employment). Seorang wirausahawan membeli barang saat ini pada harga tertentu dan menjualnya pada masa yang akan datang dengan harga tidak menentu. Jadi definisi ini lebih menekankan pada bagaimana seseorang menghadapi resiko atau ketidakpastian. Seorang wirausahawan adalah agen yang menyatukan berbagai alat-alat produksi dan menemukan nilai dari produksinya. Sementara itu, Joseph Schumpeter (1934) menyatakan wirausahawan pada dasarnya adalah seorang inovator yang mengimplementasikan perubahan-perubahan di dalam pasar melalui kombinasi-kombinasi baru. Kombinasi baru tersebut bisa dalam bentuk: (1) memperkenalkan produk baru atau dengan kualitas baru, (2) memperkenalkan metoda produksi baru, (3) membuka pasar yang baru (new market), (4) memperoleh sumber pasokan baru dari bahan atau komponen baru, atau (5) menjalankan organisasi baru pada suatu industri. Schumpeter mengkaitkan wirausaha dengan konsep inovasi yang diterapkan dalam konteks bisnis serta mengkaitkannya dengan kombinasi sumber daya.

Seorang wirausahawan selalu diharuskan menghadapi resiko atau peluang yang muncul, serta sering dikaitkan dengan tindakan yang kreatif dan innovatif. Selain itu, seorang wirausahawan menjalankan peranan manajerial dalam kegiatannya, tetapi manajemen rutin pada operasi yang sedang berjalan tidak digolongkan sebagai kewirausahaan. Seorang individu mungkin menunjukkan fungsi kewirausahaan ketika membentuk sebuah organisasi, tetapi selanjutnya menjalankan fungsi manajerial tanpa menjalankan fungsi kewirausahaannya. Kewirausahaan adalah penerapan kreativitas dan keinovasian untuk memecahkan permasalahan dan upaya memanfaatkan peluang-peluang yang dihadapi orang setiap hari.

Instruksi Presiden Republik Indonesia (INPRES) No. 4 Tahun 1995 tentang Gerakan Nasional Me-masyarakat-kan dan Mem-budaya-kan Kewirausahaan menyatakan yang dimaksud dengan kewirausahaan adalah semangat, sikap, prilaku dan kemampuan seseorang dalam menangani usaha dan/atau kegiatan yang mengarah pada upaya mencari menciptakan, menerapkan cara kerja, teknologi dan produk baru dengan meningkatkan efesiensi dalam rangka memberikan pelayanan yang lebih baik dan/atau memperoleh keuntungan yang lebih besar. Seorang sarjana yang tidak memiliki etos kewirausahaan, niscaya mereka tidak akan mampu mengembangkan usaha mandiri.

Dalam iklim persaingan usaha yang makin tidak ramah, peluang untuk mengembangkan usaha mandiri, selain membutuhkan dukungan modal yang memadai dan akses pada pasar yang kuat, secara teoritis yang tak kalah penting adalah modal sosial pengetahuan dan etos kewirausahaan yang dimiliki sejak seseorang mulai mengenal dunia pendidikan, terlebih di jenjang Perguruan Tinggi (Danim 2003). Pengalaman selama kuliah, teori yang mereka pelajari, diskusi kasus dan lain sebagainya adalah bagian dari proses pembelajaran yang dibutuhkan seseorang --tak terkecuali sarjana ekonomi-- untuk modal mengembangkan usaha mandiri.

Studi yang tengah dilaporkan ini bermaksud mengkaji berbagai kendala yang dihadapi sarjana lulusan fakultas ekonomi dan bisnis dalam mengembangkan usaha mandiri, memetakan kemampuan mereka dalam membangun jaringan kerja, serta sekaligus merumuskan program intervensi yang benar-benar kontekstual untuk mempercepat upaya penanganan pengangguran, khususnya pengangguran terdidik di Provinsi Jawa Timur.

\section{Metode Penelitian}

Kegiatan ini pada dasarnya merupakan kegiatan penelitian lapangan yang dilakukan dengan tujuan selain berusaha memetakan persoalan prioritas yang sedang dialami Propinsi Jawa Timur dalam upaya penanganan persoalan pengangguran terdidik, juga sekaligus berusaha 
merumuskan arah kebijakan serta program intervensi yang benar-benar efektif dan kontekstual dalam rangka menciptakan lapangan pekerjaan bagi para pengangguran yang ada, khususnya pengangguran terdidik di bidang ilmu ekonomi dan bisnis.

Kegiatan pengkajian di lapangan dilakukan di 2 daerah terpilih yang ditengarai rawan atau tengah menghadapi permasalahan tenaga kerja, khususnya persoalan pengangguran terdidik, yaitu Kota Surabaya dan Kota Malang. Jumlah pengangguran terdidik yang diwawancarai dan digali aspirasinya sebanyak 100 responden. Kriteria responden adalah: (1) sarjana lulusan Fakultas Ekonomi dan Bisnis, (2) dalam dua tahun terakhir, responden minimal pernah sekali menganggur atau kehilangan mata pencaharian karena situasi pasar yang tidak kondusif, dan (3) pernah memiliki pekerjaan atau usaha mandiri yang menjadi mata pencaharian tetapnya.

Seluruh data yang berhasil dikumpulkan, setelah melalui proses editing dan klasifikasi kemudian telah dianalisis dan diinterpretasi. Sepanjang memungkinkan, data yang diperoleh akan ditampilkan dalam bentuk tabel atau grafik sederhana yang mudah dipahami, dan matriks yang berisikan program-program apa yang mendesak direkomendasikan kepada Pemerintah Provinsi Jawa Timur untuk menangani dan menyediakan lapangan kerja bagi para pengangguran terdidik yang ada. Di akhir laporan, selain ditampilkan kesimpulan hasil kajian yang telah dilakukan, juga dikemukakan sejumlah sejumlah rekomendasi tentang arah penanganan para pengangguran terdidik yang ada di Provinsi Jawa Timur, khususnya pengangguran dari bidang ilmu ekonomi dan bisnis. Program yang dirumuskan difokuskan pada upaya untuk mendorong perkembangan usaha yang sifatnya mandiri.

\section{Hasil Penelitian dan Pembahasan}

Idealnya, yang namanya sarjana, terlebih sarjana lulusan fakultas ekonomi dan bisnis tentunya diharapkan bukan hanya mampu memperlihatkan kinerja yang profesional di bidang pekerjaannya, melainkan juga memiliki kemampuan untuk membangun usaha mandiri tanpa harus tergantung pada lapangan kerja di pasaran. Berbeda dengan lulusan program Diploma II atau III yang memang lebih banyak dipersiapkan untuk mengisi lowongan kerja praktis di pasaran, yang namanya sarjana ekonomi sebetulnya diharapkan memiliki bekal akademis dan potensi keahlian untuk mengembangkan usaha mandiri yang dapat menciptakan lapangan kerja baru daripada berharap dapat mengisi lapangan kerja yang ditawarkan perusahaan atau pelaku ekonomi yang lain. Apakah harapan ini telah dan dapat tercapai?

Dalam kasus-kasus tertentu, barangkali benar bahwa sejumlah sarjana ekonomi telah memperlihatkan kemampuan dan kreativitasnya untuk membangun dan mengembangkan usaha-usaha mandiri yang memadai. Seperti bisa dibaca di media massa, dalam beberapa kasus memang terkadang diekspose sarjana ekonomi yang sukses membangun usaha sendiri, bahkan dengan skala usaha yang mencengangkan. Tetapi, dalam kenyataan yang namanya sarjana ekonomi ternyata tidak semua mampu mengembangkan usaha yang sifatnya mandiri. Mengembangkan usaha kreatif yang mandiri, bagi lulusan sarjana ekonomi ternyata bukan hal yang mudah. Dari 100 sarjana ekonomi yang diteliti, hanya 32\% yang berhasil membangun usaha mandiri terlepas apakah skala usaha mandiri yang mereka kembangkan kecil, menengah atau besar. Itu pun waktu yang dbutuhkan juga tidaklah sebentar. Untuk membangun sebuah usaha mandiri, dari 32 lulusan sarjana ekonomi yang diteliti mengaku paling-tidak membutuhkan waktu 1-2 tahun (25\%). Sebagian besar responden bahkan mengaku mereka membutuhkan waktu 3-4 tahun untuk dapat mengembangkan usaha mandiri, bahkan sebagian besar $(43,7 \%)$ membutuhkan waktu antara 5-6 tahun. 
Tabel 1.

Riwayat kerja dan usaha yang ditekuni

\begin{tabular}{|c|c|c|}
\hline Kepemilikian koneksi seperti & Tidak punya & $42.0 \%$ \\
\hline kerabat, teman, tetangga yang & Ada, sedikit & $35.0 \%$ \\
\hline $\begin{array}{l}\text { dapat dijadikan koneksi untuk } \\
\text { mengembangkan usaha mandiri }\end{array}$ & Ada, banyak & $23.0 \%$ \\
\hline Rentang waktu antara lulus & 1-2 tahun & $25.0 \%$ \\
\hline hingga mampu mengemba- & 3-4 tahun & $31.3 \%$ \\
\hline ngkan usaha mandiri $(\mathrm{N}=32)$ & $5-6$ tahun & $43.7 \%$ \\
\hline Sumber permodalan dari usaha & Tabungan sendiri & $31.3 \%$ \\
\hline mandiri yang ditekuni & Bantuan orang tua/keluarga & $28.1 \%$ \\
\hline responden $(\mathrm{N}=32)$ & $\begin{array}{l}\text { Pinjaman lembaga kredit } \\
\text { informal }\end{array}$ & $25.0 \%$ \\
\hline & $\begin{array}{l}\text { Pinjaman dari lembaga kredit } \\
\text { formal }\end{array}$ & $15.6 \%$ \\
\hline Sumber ide yang diperoleh & Ide sendiri & $33.0 \%$ \\
\hline responden dalam menekuni & Ide orang tua/keluarga & $23.0 \%$ \\
\hline usaha mandiri yang dimiliki & Ide teman & $12.0 \%$ \\
\hline saat ini & $\begin{array}{l}\text { Ide dari media/membaca/ } \\
\text { searching di internet }\end{array}$ & $32.0 \%$ \\
\hline Kemampuan responden lebih & Mengembangkan usaha mandiri & $41.0 \%$ \\
\hline $\begin{array}{l}\text { sesuai mengembangkan usaha } \\
\text { mandiri atau bekerja ikut orang } \\
\text { lain }\end{array}$ & Ikut orang lain & $59.0 \%$ \\
\hline Peluang responden & Prospektif & $21.0 \%$ \\
\hline mengembangkan usaha mandiri & Kecil & $48.0 \%$ \\
\hline & Sama sekali tidak ada peluang & $31.0 \%$ \\
\hline Prioritas pertimbangan & Asalkan bekerja halal & $26.0 \%$ \\
\hline responden dalam & Yang penting gajinya memadai & $34.0 \%$ \\
\hline mengembangkan usaha mandiri & Yang penting sesuai bidang & \\
\hline & keahlian/bidang ilmu & $25.0 \%$ \\
\hline & $\begin{array}{l}\text { Yang penting bisa dipakai } \\
\text { sebagai batu loncatan }\end{array}$ & $15.0 \%$ \\
\hline Peluang responden untuk & Lemah & $51.0 \%$ \\
\hline mengakses sumber-sumber & Cukup besar & $33.0 \%$ \\
\hline permodalan murah & Besar & $16.0 \%$ \\
\hline Kemampuan responden untuk & Jelas tidak mampu & $15.0 \%$ \\
\hline bertahan hidup secara mandiri & Kemungkinan tidak mampu & $25.0 \%$ \\
\hline dengan kondisi saat ini & Ragu-ragu & $33.0 \%$ \\
\hline & Kemungkinan mampu & $19.0 \%$ \\
\hline & Jelas mampu & $8.0 \%$ \\
\hline
\end{tabular}

Kesulitan yang dihadapi para sarjana ekonomi untuk membangun usaha mandiri satu dan yang lain tentu berbeda-beda. Selain keterbatasan modal, salah satu problema yang dihadapi para sarjana ekonomi adalah karena mereka sebagian besar tidak memiliki koneksi (42\%) yang bisa diandalkan untuk membangun jaringan kerja dan dukungan dalam pengembangan usaha mandiri. Dari 100 pengangguran terdidik yang diteliti, hanya $23 \%$ responden yang mengaku memiliki banyak koneksi. Sebanyak 35\% responden mengaku memiliki koneksi, tetapi jumlahnya hanya sedikit, sehingga tidak banyak peluang yang bisa dimanfaatkan. 
Dalam hal memilih jenis usaha apa yang dicoba dikembangkan secara mandiri, sebagian besar sarjana ekonomi yang diwawancarai sebetulnya mengaku berasal dari inisiatif mereka sendiri. Sebanyak 33\% responden menyatakan ide menekuni usaha mandiri yang dikembangkan saat ini berasal dari idenya sendiri, dan $32 \%$ yang lain mengaku idenya mereka peroleh dan berasal dari media media. Sebanyak $23 \%$ mengaku idenya dari orang tua, dan $12 \%$ idenya berasal dari teman. Sebagai orang yang pernah belajar ilmu ekonomi, di tingkat gagasan sebetulnya banyak dari responden yang mengaku memiliki rencana atau keinginan untuk mengembangkan usaha mandiri yang menguntungkan. Tetapi, karena situasi pasar yang makin kompetitif, keterbatasan modal yang dimiliki dan lain-lain, diakui sejumlah informan yang diwawancarai secara mendalam bahwa untuk mewujudkan rencana mereka ternyata tidaklah mudah. Untuk membangun sebuah usaha mandiri, selain modal, yang dibutuhkan bukan hanya akses pada pasar, tetapi juga keunggulan untuk bersaing di pasar yang makin mengglobal.

Studi ini menemukan, sumber permodalan dari usaha mandiri yang dikembangkan 32 sarjana ekonomi yang diteliti, sebagian besar berasal dari tabungan sendiri $(31,3 \%)$. Sebanyak $28,1 \%$ responden mengaku modal usaha mereka berasal dari bantuan orang tua atau keluarga. Sebanyak $25 \%$ berasal dari pinjaman lembaga kredit informal, dan 15,6\% berasal dari pinjaman lembaga kredit formal. Sudah barang tentu, jika responden meminjam ke lembaga kredit fotmal maupun informal, mereka biasanya akan dibebani dengan kewajiban membayar suku bunga pinjaman yang acapkali tidak ringan. Sejumlah informan mengakui bahwa mereka tidak memiliki keberanian untuk meminjam modal kepada lembaga kredit tertentu, karena implikasinya ke belakang disadari sangatlah berat. Ketika upaya membangun usaha mandiri membutuhkan modal yang tidak sedikit dan ketika disadari iklim pasar acapkali tidak ramah, maka pilihan realistis yang seringkali diakui responden adalah menunda mengembangkan usaha sendiri, dan kemudian lebih memilih bekerja ikut orang lain agar resiko yang ditanggung tidak terlalu besar.

Sebagian besar sarjana ekonomi yang diteliti menyatakan dengan kemampuan yang dimiliki, mereka sebetulnya merasa lebih cocok jika bekerja ikut orang lain atau bekerja di perusahaan (59\%). Dari 100 sarjana lulusan fakultas ekonomi dan bisnis, hanya $41 \%$ responden yang mengaku berkeinginan untuk mengembangkan usaha mandiri. Banyak sarjana ekonomi lebih memilih bekerja ikut orang lain, karena hal itu dinilai lebih sesuai dengan kondisi sosialekonomi mereka saat ini.

Studi ini menemukan bahwa sebagian besar peluang sarjana ekonomi untuk mengembangkan usaha mandiri umumnya kecil, bahkan nyaris tidak ada. Hanya $21 \%$ responden yang menyatakan peluang mereka mengembangkan usaha mandiri prospektif. Sebagian besar responden (48\%) menyatakan peluangnya kecil, dan bahkan $31 \%$ responden benar-benar pesimis karena mereka yakin sama sekali tidak memiliki peluang untuk mengembangkan usaha mandiri.

Kendala yang acapkali dihadapi para sarjana ekonomi untuk mengembangkan usaha mandiri adalah pertama-tama karena peluang mereka untuk mengakses sumber-sumber permodalan murah umumnya lemah. Separuh lebih responden menyatakan bahwa mereka tidak memiliki akses yang memadai yang bisa diandalkan untuk mendapatkan modal usaha (51\%). Hanya $16 \%$ responden yang mengaku peluang mereka mengembangkan usaha dan mengakses modal relatif besar. Sebanyak 33\% responden menyatakan peluang mengakses sumber permodalan murah cukup besar. 
Tabel 2.

Kendala yang dihadapi sarjana ekonomi dalam mencari kerja atau mengembangkan usaha mandiri

\begin{tabular}{lcccc}
\hline \multicolumn{1}{c}{ Kendala } & $\begin{array}{c}\text { Sangat } \\
\text { menghamba } \\
\text { t }\end{array}$ & $\begin{array}{c}\text { Menghamba } \\
\text { t }\end{array}$ & $\begin{array}{c}\text { Cukup } \\
\text { menghamba } \\
\text { t }\end{array}$ & $\begin{array}{c}\text { Tidak } \\
\text { menghamb } \\
\text { at }\end{array}$ \\
\hline 1. $\begin{array}{l}\text { Keterbatasan modal } \\
\text { usaha }\end{array}$ & $28.0 \%$ & $32.0 \%$ & $23.0 \%$ & $17.0 \%$ \\
2. Akses ke sumber & $27.0 \%$ & $34.0 \%$ & $20.0 \%$ & $19.0 \%$ \\
$\begin{array}{l}\text { permodalan } \\
\text { lemah/kurang }\end{array}$ & & & & \\
3. $\begin{array}{l}\text { Koneksi terbatas } \\
\text { Orang tua secara }\end{array}$ & $24.0 \%$ & $45.0 \%$ & $21.0 \%$ & $10.0 \%$ \\
$\begin{array}{l}\text { ekonomi lemah } \\
\text { Jumlah saudara }\end{array}$ & $25.0 \%$ & $30.0 \%$ & $26.0 \%$ & $19.0 \%$ \\
$\begin{array}{l}\text { banyak } \\
\text { Kemampuan } \\
\text { berbahasa asing }\end{array}$ & $22.0 \%$ & $24.0 \%$ & $30.0 \%$ & $24.0 \%$ \\
$\begin{array}{l}\text { kurang } \\
\text { Kompetiter terlalu } \\
\text { banyak }\end{array}$ & $19.0 \%$ & $40.0 \%$ & $29.0 \%$ & $12.0 \%$ \\
\hline
\end{tabular}

Secara lebih rinci, studi ini menemukan sejumlah kendala utama yang menghambat upaya pengembangan usaha mandiri adalah: Pertama, karena iklim persaingan yang makin ketat dan jumlah kompetitor pelaku ekonomi yang makin banyak. Sebanyak 29\% responden menyatakan jumlah kompetitor yang terlalu banyak sangat menghambat. Kedua, keterbatasan modal usaha (28\%), dan kurangnya akses ke sumber-sumber permodalan (27\%) yang memungkinkan responden dapat memanfaatkannya untuk mengembangkan usaha mandiri. Ketiga, tidak adanya dukungan dana dari keluarga, karena kondisi ekonomi orang tua yang rentan $(25 \%)$--ditambah jumlah koneksi yang terbatas (24\%). Bagi para sarjana ekonomi, akumulasi dari berbagai kendala ini, seringkali membuat peluang mereka untuk membangun usaha mandiri menjadi jauh lebih sulit.

Dalam memilih usaha apa yang ingin dikembangkan, para sarjana ekonomi yang diteliti menuturkan ada beberapa kriteria yang selalu dipertimbangkan. Selain diharapkan bisa menghasilkan pendapatan yang besar (43\%), hal lain yang dipertimbangkan responden adalah pekerjaan atau usaha yang ditekuni tidak mengharuskan mereka pisah dengan keluarga (48\%), sesuai minat mereka (40\%), sesuai dengan latar belakang pendidikan yang mereka jalani, tidak berat (32\%), dan resikonya kecil (31\%). Usaha yang prospektif dan menjanjikan keuntungan yang besar umumnya merupakan usaha yang ingin dikembangkan responden. Hanya saja, diakui untuk mencari atau menemukan usaha seperti itu bukanlah hal yang mudah. Sering terjadi, sebuah usaha yang dirasa sangat prospektif, tetapi ketika ditimbangtimbang, ternyata jumlah pesaing sudah sangat banyak, sehingga mereka kemudian memilih mundur sebelum benar-benar mencobanya dalam kenyataan.

Di masa mendatang, beberapa hal yang dibutuhkan para sarjana ekonomi untuk dapat mengembangkan usaha yang sifatnya mandiri, selain bantuan modal usaha murah (32\%) dan akses ke sumber permodalan (31\%), yang tak kalah penting adalah koneksi (32\%) dan informasi pasar yang bisa dijadikan pintu untuk membuka pangsa pasar yang prospektif (29\%). Sebanyak 23\% responden menyatakan sangat membutuhkan bantuan teknologi peralatan, dan $23 \%$ responden juga menyatakan sangat membutuhkan pelatihan ketrampilan yang bisa dijadikan bekal para sarjana ekonomi untuk membangun usaha mandiri. 


\section{Simpulan}

Di atas kertas, yang namanya sarjana lulusan Fakultas Ekonomi dan Bisnis seharusnya memiliki bekal pengetahuan yang lebih siap untuk berkompetisi dalam situasi pasar bebas dan lebih siap untuk mengembangkan berbagai usaha yang sifatnya mandiri. Dalam kenyataan ternyata tidak selalu sarjana yang selama kuliah menekuni bidang ekonomi mampu mengembangkan usaha kreatif secara mandiri. Akibat keterbatasan modal dan kurangnya akses pada pasar, menyebabkan usaha yang ditekuni para lulusan PT di bidang ekonomi ini tidak berjalan sebagaimana diharapkan.

Studi sebagai dilaporkan menemukan bahwa usaha yang dikembangkan para sarjana ekonomi umumnya merupakan usaha kecil berskala lokal dan tidak memiliki daya kompetitif yang kuat. Sebagian besar sarjana ekonomi yang diteliti mengaku pesimis dengan masa depan usahanya, dan bahkan tidak sedikit yang mengaku prospek perkembangan usahanya ke depan suram, karena berbagai keterbatasan yang dihadapi. Kendala yang acapkali dihadapi sarjana ekonomi ini, adalah keterbatasan modal dan jumlah kompetitor yang terlalu banyak. Di era iklim persaingan usaha yang makin ketat, diakui sulit bagi mereka untuk dapat mengembangkan usaha mandiri, terutama ketika mereka tidak memiliki dukungan modal yang cukup dan akses pada pasar yang bisa diandalkan.

Mewujudkan sarjana yang memiliki semangat kewirausahaan dan secara mandiri mampu mengembangkan usaha yang dapat dijadikan tempat bergantung hidup harus diakui bukan hal yang mudah. Selain perbaikan kurikulum dan aktivitas belajar yang lebih memfasilitasi peluang lulusan untuk belajar praktik berbisnis, yang tak kalah penting adalah bagaimana membangun konstruksi sosial agar para sarjana terdidik siap sejak awal menghadapi pasar dan era persaingan bebas yang sudah ada di depan mata.

\section{Daftar Pustaka}

Basri F (2002) Perekonomian Indonesia: Tantangan dan harapan bagi kebangkitan Indonesia. Jakarta: Erlangga.

Cantillon R (2010) An essay on economic theory. Alabama: von Mises Intitute.

Danim S (2003) Ekonomi sumber daya manusia. Bandung: Pustaka Setia.

Kuncoro M (2003) Ekonomi pembangunan, teori, masalah dan kebijakan. Yogyakarta: UPP AMP YKPN.

Manning C \& Diermen PV (2000) Indonesia di tengah transisi. Yogyakarta: LKIS.

Nugroho I \& Dahuri R (2004) Pembangunan wilayah, perspektif ekonomi, sosial dan lingkungan. Jakarta: LP3ES.

Pacione M (ed.) (1986) Population geography: Progress \& prospect. New York: Routledge.

Suyanto B, Sutinah, Ariadi S \& Budirahayu T (2013) Penanganan pengangguran terdidik di Jawa Timur. Surabaya: Lembaga Penelitian dan Pengabdian kepada Masyarakat Universitas Airlangga.

Suyanto B (2006) Penyusunan kebijakan dan program penanggulangan masalah pengangguran di Jawa Timur. Kerjasama LPPM Universitas Airlangga dan Bappeprop Jawa Timur.

Suyanto B \& Karnaji (2005) Kemiskinan dan kesenjangan: Ketika pembangunan tak berpihak rakyat. Surabaya: Airlangga University Press.

Tirtosudarmo R (1994) Dinamika penduduk dan ketenagakerjaan pemuda perkotaan Indonesia. Jakarta: Grasindo.

Yustika AE (2007) Perekonomian Indonesia, satu dekade pascakrisis ekonomi. Malang: Badan Penerbit Fakultas Ekonomi Universitas Brawijaya (BPFE Unibraw). 